\title{
The Influence of Think Pair Share Model Assisted by Mind Mapping Media at Fourth Grade Science Competence
}

\author{
Anak Agung Wisnuardani \\ Program Studi Pendidikan Guru Sekolah Dasar, Universitas Pendidikan Ganesha, Singaraja, Indonesia \\ email: agunganiagung16@gmail.com
}

Ida Bagus Gede Surya Abadi

Program Studi Pendidikan Guru Sekolah Dasar, Universitas Pendidikan Ganesha, Singaraja, Indonesia email: idabagusgedesurya.abadi@undiksha.ac.id

\section{A R T I C L E I N F O \\ Article history: \\ 1 Agustus 2020 Received in revised form \\ 20 September 2020 \\ Accepted 10 November 2020 \\ Available online 20 \\ November 2020

Kata Kunci:
$T P S, \quad$ mind $\quad$ mapping,
pengetahuan IPA

TPS, mind mapping, science

knowledge.
Keywords:

\begin{abstract}
A B S T R A K
Penerapan model think pair share dilakukan untuk meningkatkan semangat belajar IPA berbantuan Mind Mapping pada siswa kelas IV SD. Tujuan penelitian ini untuk mengetahui pengaruh model think pair share berbantuan media mind mapping terhadap kompetensi pengetahuan IPA kelas IV SD. Jenis penelitian ekserimen semu (quasi ekserimen) menggunakan rancangan Nonequivalent Control Group Design. Populasi dalam penelitian berjumlah 153 siswa yaitu seluruh kelas IV SD. Pengambilan sampel menggunakan teknik random sampling yaitu mengacak kelas. Sampel terpilih adalah SD dengan jumlah siswa 31 siswa sebagai kelas eksperimen dan SD dengan jumlah 30 siswa sebagai kelas kontrol. Data kompetensi Pengetahuan IPA dikumpulkan menggunakan tes objektif. Analisis data menggunakan uji-t. Hasil analisis uji-t diperoleh thitung $=7,104>$ $\mathrm{t}_{\text {tabel }}=2,000$, pada taraf signifikansi $5 \%$ dengan $\mathrm{dk}=59$. Ini berarti terdapat perbedaan yang signifikan kompetensi pengetahuan IPA antara siswa yang dibelajarkan menggunakan model think pair share berbantuan media mind mapping dengan siswa yang dibelajarkan menggunakan pembelajaran konvensional kelas IV SD. Demikian nilai ratarata kompetensi pengetahuan IPA kelompok eksperimen $\bar{x}=83.30>\overline{\mathrm{x}}=67,96$ rata-rata
\end{abstract} nilai kelompok kontrol. Dengan demikian dapat disimpulkan bahwa terdapat pengaruh model think pair share berbantuan media mind mapping terhadap kompetensi pengetahuan IPA kelas IV SD.

\section{A B S T R A C T}

The application of the think pair share model is carried out to increase the enthusiasm for learning science with the help of Mind Mapping in grade IV SD students. This study aims to determine the effect of think pair share with the mind mapping media for science knowledge competency of the fourth grade students at elementary school. This type of quasi-experimental research (quasi-experimental) used the Nonequivalent Control Group Design. The population in school lessons is 153 students, all grade IV SD. Sampling using random sampling technique, randomizing the class. The selected sample was SD with 31 students as the experimental class and SD with 30 students as the control class. Science knowledge competency data were collected using objective tests. Data analysis using t-test. The results of the t-test analysis obtained tcount $=7.104>$ ttable $=$ 2,000 , at a significance level of $5 \%$ with $\mathrm{dk}=59$.It means that there is a significant difference in the competence of science knowledge between students who are taught using think pair share models assisted by mind mapping media and students being taught using conventional class IV SD learning. The average score of knowledge competency in the science experimental group $\mathrm{x}^{-}=83.30>\mathrm{x}^{-}=67.96$ the mean scoree of the control group. Thus it can be ignored that there is an influence of the think pair share model assisted by mind mapping media on the competence of science knowledge in grade IV SD.

\section{Introduction}

The learning process is a complex series of events. There is a reciprocal relationship between students and teachers. The learning process is hoped that student behavior changes will arise (Sari et al., 2018). One of the lessons that elementary students get is science. Science is one of the main subjects in Indonesia's education curriculum, including at the elementary school level (Agung et al., 2017; Juniati \& Widiana, 2017). Science is not only the mastery of a collection of knowledge in the form of facts, concepts, or principles but is also a process of discovery (Panjaitan, 2017). In science learning, usually, there are practicum activities, looking for information and analyzing (Pitriani et al., 2017). In the sense of students who think and build their knowledge. However, this is rarely done because students tend to be passive and recipients of information, and some students consider science difficult. Based on a document study at SD Cluster 1 Tegallalang Gianyar on October 31 and November 4th 2019, the science subject found a problem: the results of competency in science knowledge were not optimal. It is known after carrying out observations and interviews with the school principal and class IV homeroom teacher. The not 
yet optimal competence in scientific knowledge is known from the semester 1 UTS scores. There are still those who have not reached the KKM. SD Negeri 1 Tegallalang there are $16.12 \%$ of students still below KKM 78. For SD Negeri 3 Tegallalang there are $17.24 \%$ of students under KKM 65, SD Negeri 4 Tegallalang there are $40 \%$ students under KKM 74, SD Negeri 5 Tegallalang is $65.71 \%$ of students under KKM 72 and SD Negeri 6 Tegallalang amounted to $28.57 \%$ of students under KKM 67 . These problems occur due to various reasons, : first, students are less enthusiastic when learning science. Students do not understand the material provided by the teacher so that their knowledge competencies are less than optimal. Second, students are only recipients of information who tend to be passive and do not have enough practice to build their knowledge. Students tend to forget the previous material that has been given by the teacher. Third, students are less active in class. During the lesson, some students dared to ask questions and some tended to be less courageous in expressing their questions or opinions. Fourth, the use of learning media is still limited, so that students do not explore their abilities. The use of media in learning is very important, this is because media is a tool that supports the learning process. Fifth, the atmosphere in the classroom is not conducive. During group discussions or working on group assignments, students tend to be less serious and talk more. Seeing these problems, innovation is needed so that the implementation of learning takes place effectively and pleasantly. One of these innovations is to use a learning model that fits the needs and conditions of students in the classroom and produces fun learning activities. To prepare for learning, the teacher must understand the characteristics of the learning material, the students' characteristics, and understand the methodology that impacts increasing the activities of students. Many efforts can be made to create a conducive learning atmosphere so that students experience meaningful learning, including trying various learning models that are considered appropriate to students' conditions in the class and the material to be taught. (Mawaddah \& Anisah, 2015). Applying the learning model appropriately will increase students' enthusiasm, enthusiasm, and activeness (Febrianto, 2016).

One of the innovative learning models that can be used is the Think Pair Share learning model. The think pair share model is cooperative learning that activates effective communication relationships between students to form children's social interactions (Aziza et al., 2019; Kusuma \& Aisyah, 2012; Muthoharoh, 2017). Think Pair Share (TPS) is a type of cooperative learning designed in the form of discussion that can improve students' thinking skills, communication skills and encourage their class participation. This model shapes the character of students to respect the opinions of friends and express personal opinions. TPS is an effective way to create a variety of atmosphere in the class discussion patterns (Nurnawati et al., 2012; Supatni et al., 2015). Think Pair Share prioritizes cooperative learning that allows students to help each other and interact with one another (Lestari \& Widyaningrum, 2016; Wulandari et al., 2018). The Think Pair Share (TPS) type of cooperative learning model is an effective learning model to increase student learning activities because students must do more activities while studying. With the TPS learning model, students will be more motivated in the learning process to impact student learning outcomes (Tembang et al., 2017). The TPS learning model's application improves mathematical communication skills and students' self-confidence (Dharma et al., 2019).

The selection of the right model impacts the science knowledge competence of students to support the application of the learning model, tools, or facilities are needed. It attracts students' attention and maximizes learning activities. Therefore we need a medium that can attract students' attention in the form of Mind Mapping. Media is a tool or intermediary that is used as a means used to convey learning material to students. The existence of learning media will facilitate the learning process. It can increase student interest in the learning process (Seika et al., 2017) and increase student motivation, impacting student learning outcomes (Malalina \& Kesumawati, 2014). One of the learning media that can be used is Mind Mapping. Mind mapping is a powerful organizational thinking tool that puts information into the brain and retrieves that information when needed (Setiawan, 2017). Mind mapping can see the overall picture of the material clearly and make it easier to concentrate (Nuriani, 2014). Mind Mapping helps students and teachers in the classroom's learning process by summarizing so many teaching materials into a few and interesting to read (Susanti, 2016). Mind mapping is a creative, effective way of noting and mapping thoughts (Anastasia, 2017; Imaduddin \& Utomo, 2012; Wana et al., 2017). Mind mapping is an innovative technique that can help unlock all the brain's hidden potentials and capacities (Suwitri et al., 2013), and put information into the brain, and take it back outside the brain (Arsana et al., 2019). Mind Map will help anyone increase the speed of thinking, provide unlimited flexibility, and explore far from their own thoughts (Puspita et al., 2017).

These descriptions can be said that the collaboration of the TPS learning model with Mind Mapping media will positively impact the learning process. With this learning, students can build their knowledge, and students are assisted to learn because the learning process activates more students in the learning process. Students learn either independently or in groups. Students are allowed to build their knowledge through learning steps and learning media. Learning models following student characteristics, material, and student conditions will make the learning atmosphere more fun and interesting. It will impact students' interest in the learning process, which affects the achievement of learning objectives. 


\section{Method}

The research was carried out at SD Negeri 1 Tegallalang, located at Jalan I Wayan Lunga Penusuan Tegallalang and SD Negeri 4 Tegallalang, located at Jalan Kendran Tegallalang. This research started from the observation stage related to the learning activities carried out and the collection of data on the number of students in each SD in Tegallalang Cluster 1 and followed by preparing proposals, proposal seminars, research implementation, data analysis, and thesis preparation. The implementation of each sample was carried out from January to February 2020 by giving six treatments. This type of quantitative research with experimental design is a quasi experiment. Experiment or quasi-experiment is an experimental design that allows the researcher to control as many variables as possible from the existing situation. This design does not fully control the variables as in the actual experiment, but the researcher can consider any variables that are impossible to control. The experimental design used is Nonequivalent Control Group Design (Subekti \& Ariswan, 2016). This study used a quasiexperimental research model, conducted in two classes: the experimental and control classes. In this design, there is an experimental group and a control group. Each of these groups was both given a pretest. The pretest is used to equalize the group. After that, giving treatment to each group was then given a post-test to determine the students' competency in science knowledge. The technique used in group equalization was using the t-test.

The steps for implementing the research were 1) preparation, 2) implementation, and 3) final research. In the preparatory step, interviews were conducted with the principal and fourth-grade homeroom teacher regarding the material to be given, consulted the pretest and post-test research instruments, randomized the entire population to find the sample, gave a pretest to both samples then drew the sample to determine the experimental and control groups. In the implementation of the research, it was started by giving treatment to the experimental group, applying the think pair share model assisted by mind mapping media. In contrast, in the control group, conventional learning was carried out. The total of each treatment is six times. In the final step of the research, the two groups were given a post-test, then data analysis and hypothesis testing were carried out and compiled a research report. The population consisted of 153 students taken from grade four at SD Gugus 1 Tegallalang Gianyar. The technique used is random sampling / random group sampling because the class has been formed not to change the individuals in the class. In the study, there were two draws. The first draw is to choose a sample. After the selected sample is given a pretest to equalize the t-test, the prerequisite analysis test is carried out first. After that, the second drawing was carried out, drawing a sample to select an experimental class that applied a think pair share model assisted by mind mapping media and a control class that followed conventional learning.

From the draw's results, the experimental group was the fourth grade SD Negeri 1 Tegallalang, and the control group was the fourth grade SD Negeri 4 Tegallalang. Sample equalization was carried out by analyzing the pretest results using the t-test. Before equalizing the sample, the normality test of data distribution and homogeneity of variance is carried out, which is called the prerequisite test for data analysis. The data distribution normality test was calculated using the Kolmogorov-Smirnov formula. The criterion for the normality test is if the maximum score $\left|F_{T}-F_{S}\right| \leq$ the score of the Kolmogorov-Smirnov table, then Ho is accepted, and Ha is rejected, which means that the data distribution is normally distributed, whereas if the maximum score is $\left|F_{T}-F_{S}\right|>$ Kolmogorov-Smirnov table score, then Ho is rejected, and Ha is accepted, which means that the data distribution is not normally distributed at the $5 \%$ significance level. The test used is the usual multiple-choice. Before the test is given, the instrument validation is carried out. The tests' preparation is based on indicators of the content of science material and is adjusted to the theme. The test items are arranged based on a grid so that the resulting test does not deviate. Still, before the test is given, the validity test is carried out, the item validity test, the content validity test, the difficulty index test, the difference power test, and the reliability test. Based on the results of the validity test, there were 30 valid questions.

After all data is obtained, data analysis is carried out using inferential statistics. Magfirah (2015) states that inferential statistics are a statistical technique used to analyze sample data and apply them to the population. With the prerequisite test, the normality test, linearity, and multiple linear regression analysis. The data analysis technique used is the t-test with the polled variance formula. However, the prerequisite test is carried out first, the normality test of the data distribution using the Kolmogorov-Smirnov formula with the testing criteria if the maximum score is $\left|F_{T}-F_{S}\right| \leq \leq$ Kolmogorov-Smirnov table score, then Ho is accepted, and the data is normally distributed. Otherwise, if the maximum score ||$F_{T}-F_{S}|\geq|$ The Kolmogorov-Smirnov table's score, then Ho is rejected, and the data is not normally distributed. Furthermore, to prove the difference in the group variance, the variance test was carried out using the $F$ test with the testing criteria. If Fcount $\leq$ Ftable, then the sample was declared homogeneous. The test was carried out at $5 \%$ significance level, with the degrees of freedom for the $\mathrm{n} 1$ 1 numerator and freedom for the $\mathrm{n} 2-1$ denominator. If Fcount> Ftable then the sample is declared not homogeneous. 
Research data that have been tested for normality and tested for homogeneity are then tested for the hypothesis. The statistical hypothesis in this study is Ho, which states that there is no significant difference in science knowledge competencies between students who are taught using the think pair share model assisted by mind mapping media and students who are taught using conventional learning in fourth grade SD Gugus 1 Tegallalang Gianyar for the 2019/2020 academic year. With the test criteria, if the tcount $\leq$ ttable, then Ho is accepted and $\mathrm{Ha}$ is rejected. If the price of tcount> ttable, then Ho is rejected, and Ha is accepted. At the 5\% significant level with $\mathrm{dk}=\mathrm{n} 1+\mathrm{n} 2-$.

\section{Result and Discussion}

The data analyzed in this study used science knowledge competency data obtained based on the post-test scores. The data are grouped into two groups, the science knowledge competency data in the experimental group and the science knowledge competency data in the control group. The experimental group applied the think pair share model assisted by mind mapping media. The control group applied conventional learning, and at the end of the study, the two groups were given a post-test. After obtaining the post-test score data then the data were analyzed and obtained an average. Based on the calculation results, the post-test average of the experimental group was 83.30, while the average post-test result of the control group was 67.96. Based on the results of the calculation of the normality test of the experimental group, the maximum score of $\left|F_{T}-F_{S}\right|=0.074$ was then compared with the score of the Kolmogorov-Smirnov table with a significance level of $5 \%(\alpha=0.05)=0.238$. Because the maximum score $\left|F_{T}-F_{S}\right|=0.074<$ the score of the Kolmogorov-Smirnov table $=0.238$, the data is normally distributed. Based on the results of the calculation of the control group normality test, the maximum score is obtained $\left|F_{T}-F_{S}\right|$ $=0.136$. Then compared with the Kolmogorov-Smirnov table score with a significance level of $5 \%(\alpha=0.05)=$ 0.242 . Because the maximum score $\left|F_{T}-F_{S}\right|=0.136<$ the score of the Kolmogorov-Smirnov table $=0.242$, the data is normally distributed. The recapitulation table of the control group normality test results is presented in Table 3. After the data is tested for normality and declared as normally distributed, then proceed with the variance homogeneity test. The analysis results obtained Fcount $=1.73$ and Ftable $=1.85$ at the $5 \%$ significance level and $\mathrm{dk}=30.29$. Because Fcount $=1.73<$ Ftable $=1.85$, the two groups' data has a homogeneous variant.

After obtaining the normality test results and the homogeneity of the variance test, it is concluded that the experimental group and control group data are normally distributed and have homogeneous variances so that the hypothesis testing in this study uses the $t$-test. The test criteria if tcount $\leq$ ttable then Ho is accepted. Conversely, if tcount $>$ ttable, Ho is rejected at the 5\% significance level with indiscretion $=n_{1}+n_{2}-2$. The hypothesis tested in this study is that there is no significant difference in the competence of science knowledge between students who are taught using the think pair share model assisted by mind mapping media and students who are taught using conventional learning from fourth grade students of SD Gugus 1 Tegallalang Gianyar for the 2019/2020 academic year. Based on the analysis using the $t$-test, it was obtained $t$ count $=7.104$, while at the $5 \%$ significance level with degrees of freedom $(\mathrm{dk}=31+30-2)=59$, the obtained $\mathrm{t}$ table $=2,000$. Because tcount $>$ ttable, it can be concluded that Ho is rejected. There are differences in the competence of science knowledge between students taught using the think pair share model assisted by mind mapping media and students who are taught using conventional learning for fourth-grade students of SD Gugus 1 Tegallalang Gianyar for the 2019/2020 academic year. The average competence of science knowledge in the experimental group was 83.30, while the average competence of science knowledge in the control group was 67.96. So it is known that the mean score of the experimental group is more than the control group, $\bar{x}=83,30>\bar{x}=67,96$. It means that the application of the think pair share model assisted by mind mapping media affects the fourth-grade science competency of SD Gugus 1 Tegallalang Gianyar for the 2019/2020 academic year.

These differences show that the think pair share model assisted by mind mapping media influences students' competency in science knowledge. At first, it was known that the two groups had the same ability, which was seen based on the equivalence test by analyzing pretest data. The experimental group was given treatment to apply the think pair share model assisted by mind mapping media, while the control group was given conventional learning. The existence of this treatment shows differences in the competence of scientific knowledge between the two groups. The science competence of the experimental group was better than the control group. Students become active and can remember the material being studied because they use interesting note-taking techniques. The learning process in the experimental group was more conducive and more active. Students are trained to think independently, discuss with partners and convey the discussion results.

The Think Pair Share (TPS) type of cooperative learning model is a cooperative learning model that provides opportunities for each student to show participation to others. With this learning model, students have more opportunities to participate so that students gain greater understanding. The think pair share model is cooperative learning that activates effective communication relationships between students to form children's social interactions (Aziza et al., 2019; Kusuma \& Aisyah, 2012; Muthoharoh, 2017). Think Pair Share (TPS) is a type of cooperative learning designed in the form of discussion that can improve students' thinking skills, 
communication skills and encourage their class participation. This model shapes the character of students to respect the opinions of friends and express personal opinions. TPS is an effective way to create a variety of atmosphere in class discussion patterns (Nurnawati et al., 2012; Supatni et al., 2015). Think Pair Share prioritizes cooperative learning that allows students to help each other and interact with one another (Lestari \& Widyaningrum, 2016; Wulandari et al., 2018). Think Pair Share (TPS) type of cooperative learning model is an effective learning model to increase student learning activities because students must do more activities while studying. With the TPS learning model, students will be more motivated in the learning process to impact student learning outcomes (Tembang et al., 2017). The TPS learning model's application improves mathematical communication skills and students' self-confidence (Dharma et al., 2019). This model is easy to implement and trains students to think independently, work together by exchanging ideas. Students have the opportunity to present the results of the discussion to the whole class. The benefits of the think pair share model are (1) students can spend as much time as possible in completing assignments and understand each other with friends. There are more opportunities for students to raise their hands in learning activities after discussing with pairs because they understand better. The teacher has time to think when concentrating on listening to the results of the discussion. Students and teachers can pay attention to the behavior of each group. With this model, it can activate student participation and make the learning atmosphere fun. The Think-pair-share (TPS) type of cooperative learning model is designed so that students are trained to communicate to express various ideas that come to mind during the learning process, both to the teacher and to their friends. It can be seen from the stages of TPS learning, thinking, pairing up, and sharing. In the pairing stage and sharing the ability to communicate is very necessary to convey ideas to others to be understood (Fatimah, 2015; Hartini et al., 2016; Nataliasari, 2014; Nurjaman, 2015).

Meanwhile, mind mapping media is used to help the learning process. Students are given the freedom to be creative in terms of taking notes. With mind mapping media, students learn and practice taking notes to strengthen their memory of the material. Mind mapping is defined as an interesting note-taking style that describes what you think. Broadly speaking, mind mapping actively involves both of our brains and can help us to think creatively. (Fauzi et al., 2016) Mind Mapping uses visual and sensory reminders such as colorful pictures, symbols, sounds, and feelings in related ideas, such as a road map used for learning, organizing, and planning. Thus learning outcomes become more optimal because mind mapping media makes it easier for students to learn. Mind mapping is a powerful organizational thinking tool that puts information into the brain and retrieves that information when needed (Setiawan, 2017). Mind mapping can see the overall picture of the material clearly and make it easier to concentrate (Nuriani, 2014). Mind Mapping helps students and teachers in the classroom's learning process by summarizing so many teaching materials into a few and interesting to read (Susanti, 2016). Mind mapping is a creative, effective way of noting and mapping thoughts (Anastasia, 2017; Imaduddin \& Utomo, 2012; Wana et al., 2017). Mind mapping yang merupakan teknik inovatif yang dapat membantu membuka seluruh potensi dan kapasitas otak yang tesembunyi (Suwitri et al., 2013), serta cara untuk menempatkan informasi ke dalam otak dan mengambilnya kembali ke luar otak (Arsana et al., 2019). Mind Map akan membantu siapapun dalam meningkatkan kecepatan berpikir, memberikan kelenturan tidak terbatas, dan menjelajah jauh dari pemikiran sendiri (Puspita et al., 2017).

These descriptions can be said that the collaboration of the TPS learning model with Mind Mapping Media will positively impact the learning process. Students are allowed to build their knowledge, and students are assisted to learn because the learning process activates more students in the learning process. Students learn either independently or in groups. Students are allowed to build their knowledge through learning steps and the use of learning media. Learning models following student characteristics, material, and student conditions will make the learning atmosphere more fun and interesting. It will impact students' interest in the learning process which affects the achievement of learning objectives. Think Pair Share learning model assisted by mind mapping media emphasizes students' activeness to think about their problems. Independent thinking results are discussed with friends to get results or answers through brainstorming activities, and students are allowed to present the results of the discussion. With mind mapping media, students are more creative in recording what they have learned and making it easier for students to remember subject matter for a long time. The control group used conventional learning, which was the teacher's role, so that students were less active and students became bored quickly when attending lessons (Nurjaman, 2015). One alternative learning model is to use the Think-Pair-Share (TPS) learning model developed by Frank Lyman et al from the University of Maryland in 1985. The TPS learning model is one of the simpler cooperative learning models.

There is relevant research, research (Fauzi et al., 2016) which states that there is a significant difference in the mastery of Civics knowledge competencies between the experimental group and the control group. In addition, there is research conducted by (Wulandari et al., 2018) which concluded that there was a significant difference in the competence of science knowledge between groups of students who were taught using the portfolio-based think pair share learning model and groups of students who were taught using conventional learning models. Other research is carried out by (Adnyana et al., 2015) states that there is a significant difference in social studies learning outcomes between groups of students who learn using the type of jigsaw cooperative 
learning model assisted by mind mapping (mind maps) and groups of students who learn using conventional learning. (Dharmayanti et al., 2017)) There is a significant difference in the competence of science knowledge between the experimental and control groups.

\section{Conclusion}

There is a significant difference in the competence of science knowledge between students taught using the think pair share model assisted by mind mapping media and students who are taught using conventional learning in grade four SD Gugus 1 Tegallalang Gianyar for the 2019/2020 academic year. Students are allowed to build their knowledge, and students are assisted to learn because the learning process activates more students in the learning process. Students learn either independently or in groups. Students are allowed to build their knowledge through learning steps and the use of learning media. Learning models following student characteristics, material, and student conditions will make the learning atmosphere more fun and interesting. It will impact students' interest in the learning process, which affects the achievement of learning objectives.

\section{References}

Adnyana, G. M., Parmiti, D. P., Sumantri, M., Pendidikan, J., Sekolah, G., \& Ganesha, U. P. (2015). Pengaruh Model Kooperatif Jigsaw Berbantuan Mind. MIimbar PGSD Undiksha, 3. https://doi.org/10.23887/jjpgsd.v3i1.5812

Agung, A., Trisna, B., Candra, A., Sujana, I. W., \& Ardana, I. K. (2017). "Pengaruh Model Discovery Learning Terhadap Kompetensi Pengetahuan IPA Siswa Kelas VI Denpasar Selatan Tahun Pelajaran 2016/2017." Mimbar PGSD Undiksha, 5(2), 1-10. https://doi.org/10.23887/jjpgsd.v5i2.10655

Anastasia, M. (2017). Pengaruh Model Pembelajaran Mind Mapping Terhadap Hasil Belajar Matematika Siswa. JKPM, 2(2), 173-182. https://doi.org/http://dx.doi.org/10.30998/jkpm.v2i2.2490

Arsana, I. K., Suarjana, M., \& Arini, N. W. (2019). Pengaruh Penggunaan Mind Mapping berbantuan Alat Peraga Tangga Garis Bilangan terhadap Hasil Belajar Matematika. International Journal of Elementary Education, 3(2), 99-107. https://doi.org/http://dx.doi.org/10.23887/ijee.v3i2.18511

Aziza, R., Widodo, S. A., \& Agustito, D. (2019). Efektivitas Think Pair Share dengan Komik Ditinjau dari Kemampuan Memecahkan Masalah Matematis. Journal of Medives : Journal of Mathematics Education IKIP Veteran Semarang, 3(2), 261. https://doi.org/10.31331/medivesveteran.v3i2.858

Dharma, I., Pujiastuti, E., \& Harianja, M. (2019). Penerapan Model Pembelajaran TPS (Think-Pair-Share) untuk Meningkatkan Kemampuan Komunikasi Matematis dan Percaya Diri Peserta Didik Kelas X MIPA 1 SMA Negeri 6 Semarang Pada Materi Sistem Persamaan Tiga Variabel Tahun Pelajaran 2018/2019. PRISMA, Prosiding Seminar Nasional Matematika, 2, 239-246. https://journal.unnes.ac.id/sju/index.php/prisma/article/view/28918

Dharmayanti, N. P., Ardana, I. K., \& Suniasih, N. W. (2017). Pengaruh Model Pembelajaran Kooperatif Tipe Think Pair Share Berbasis Outdoor Study Terhadap Kompetensi Pengetahuan IPA. MIMBAR PGSD Undiksha, 5, 1-10.

Fatimah, N. (2015). Implementasi Cooperative Learning Tipe Think-Pair-Share Dalam Pembelajaran Bercerita Di Sekolah Menengah Pertama. Jurnal Penelitian Humaniora, 16(2), 90-98.

Fauzi, D. R., Kusmariyatni, N. N., \& Mahadewi, L. P. P. (2016). Pengaruh Model Pembelajaran SFAE Bermediakan Mind Mapping Terhadap Hasil Belajar PKn Siswa. E-Journal PGSD Universitas Pendidikan Ganesha, 6(3), 1-11.

Febrianto, E. (2016). Upaya Peningkatan Keaktifan dan Hasil Belajar Melalui Model Pembelajaran Think Pair Share (TPS) Berbantuan Media Power Point pada Mata Pelajaran Pengantar Ekonomi dan Bisnis Siswa SMK Negeri I Banyudono Tahun Ajaran 2015/2016. Media Konservasi, 2(1), 11-40. https://doi.org/http://dx.doi.org/10.1016/j.ecoenv.2017.03.002\%0Ahttp://www.fordamof.org/files/Sistem_Agroforestri_di_Kawasan_Karst_Kabupaten_Gunungkudul_Untuk_Pengelolaan_ Telaga_Sebagai_Sumber

Hartini, H., Maharani, Z. Z., \& Rahman, B. (2016). Penerapan Model Pembelajaran Think-Pair-Share untuk Meningkatkan Kemampuan Komunikasi Matematis Siswa SMP. Kreano, Jurnal Matematika KreatifInovatif, 7(2), 131-135. https://doi.org/10.15294/kreano.v7i2.5009 
Imaduddin, M. C., \& Utomo, U. H. N. (2012). Efektifitas Metode Mind Mapping Untuk Meningkatkan Prestasi Belajar Fisika Pada Siswa Kelas Viii. Humanitas, 9(1), $62-75$. https://doi.org/10.26555/humanitas.v9i1.350

Juniati, N. W., \& Widiana, I. W. (2017). Penerapan Model Pembelajaran Inkuiri Untuk Meningkatkan Hasil Belajar Ipa. Journal of Education Action Research, 1(2), 122. https://doi.org/10.23887/jear.v1i2.12045

Kusuma, F. W., \& Aisyah, M. N. (2012). Implementasi Model Pembelajaran Kooperatif Tipe Think Pair Share Untuk Meningkatkan Aktivitas Belajar Akuntansi Siswa Kelas Xi Ips 1 Sma Negeri 2 Wonosari Tahun Ajaran 2011/2012. Jurnal Pendidikan Akuntansi Indonesia, 10(2), $43-63$. https://doi.org/10.21831/jpai.v10i2.912

Lestari, P. B., \& Widyaningrum, D. A. (2016). Pengembangan Model Pembelajaran Reciprocal Teaching Pair Share (RTPS) Untuk Meningkatkan Kemampuan Metakognisi Matakuliah Mikrobologi Mahasiswa IKIP Budi Utomo. Jurnal Proceeding Biology Education Conference, 13(1), 528-535. https://jurnal.uns.ac.id/prosbi/article/download/5820/5206

Malalina, M., \& Kesumawati, N. (2014). Pengembangan Bahan Ajar Interaktif Berbasis Komputer Pokok Bahasan Lingkaran Untuk Kelas Viii Sekolah Menengah Pertama. Jurnal Pendidikan Matematika, 8(1). https://doi.org/10.22342/jpm.8.1.1861.55-70

Mawaddah, S., \& Anisah, H. (2015). Kemampuan Pemecahan Masalah Matematis Siswa Pada Pembelajaran Matematika dengan Menggunakag) di SMPn Model Pembelajaran Generatif (Generative Learning) di SMP. EDU-MAT: Jurnal Pendidikan Matematika, 3(2), 166-175. https://doi.org/10.20527/edumat.v3i2.644

Muthoharoh, N. B. (2017). Pengaruh Model Pembelajaran Kooperatif "Think Pair Share" terhadap Hasil Belajar Bahasa Inggris. SAP (Susunan Artikel Pendidikan), 2(1), 33-42. https://doi.org/10.30998/sap.v2i1.1509

Nataliasari, I. (2014). Penggunaan Model Pembelajaran Kooperatif Tipe Think Pair Share (TPS) Untuk Meningkatkan Kemampuan Penalaran Dan Pemecahan Masalah Matematis Siswa MTS. Jurnal Pendidikan Dan Keguruan, 1(1), 209670. https://doi.org/10.23887/jjpgsd.v5i2.10655

Nuriani, N. R. (2014). Efektifitas Penggunaan Metode Pembelajaran Inquiry Berbantuan Pendekatan Mind Mapping terhadap Kemampuan Berpikir Kritis Matematika. Jurnal Derivat, 1(1), 8-18. https://doi.org/https://doi.org/10.31316/j.derivat.v4i1.233

Nurjaman, A. (2015). Meningkatkan Kemampuan Komunikasi Matematik Siswa SMP Melalui Model Pembelajaran Kooperatif Tipe Think Pair Share (TPS). Didaktik, 9(1), 1-9.

Nurnawati, E., Yulianti, D., \& Susanto, H. (2012). Peningkatan Kerjasama Siswa Smp Melalui Penerapan Pembelajaran Kooperatif Pendekatan Think Pair Share. Unnes Physics Education Journal, 1(1). https://doi.org/10.15294/upej.v1i1.764

Panjaitan, S. (2017). Meningkatkan Hasil Belajar Ipa Melalui Media Gambar Pada Siswa Kelas Iia Sdn 78 Pekanbaru. Primary: Jurnal Pendidikan Guru Sekolah Dasar, 6(1), 252. https://doi.org/10.33578/jpfkip.v6i1.4105

Pitriani, N. W., Ardana, I. K., \& Kristiantari, M. G. R. (2017). Pengaruh Model Pembelajaran Think Pair Share Berbantuan Audio Visual Terhadap Kompetensi Pengetahuan Ips. Mimbar Pgsd, 5(2), 1-9. https://doi.org/10.23887/jjpgsd.v5i2.10789

Puspita, L., Yetri, Y., \& Novianti, R. (2017). Pengaruh Model Pembelajaran Reciprocal Teaching Dengan Teknik Mind Mapping Terhadap Kemampuan Metakognisi Dan Afektif Pada Konsep Sistem Sirkulasi Kelas Xi Ipa Di Sma Negeri 15 Bandar Lampung. Biosfer: Jurnal Tadris Biologi, 8(1), 78-90. https://doi.org/10.24042/biosf.v8i1.1265

Sari, M., Habibi, M., \& Putri, R. (2018). Pengaruh Model Pembelajaran Kooperatif Tipe Think-Pairs-Share Dalam Pembelajaran Matematika Terhadap Kemampuan Pemahaman Konsep Matematis dan Pengembangan Karakter Siswa SMA Kota Sungai Penuh. Edumatika: Jurnal Riset Pendidikan Matematika, 1(1), 7. https://doi.org/10.32939/ejrpm.v1i1.221

Seika, A. I. G. A. P. A., Kusmariyatni, N., \& Japa, I. G. N. (2017). Pengaruh Model Pembelajaran Talking Stick Berbantuan Media Question Box Terhadap Hasil Belajar Ipa Kelas V. Journal of Education Technology, 1(3), 183. https://doi.org/10.23887/jet.v1i3.12503

Setiawan, I. W. P. (2017). Pengaruh Model Pembelajaran Learning Cycle 5E Berbantuan Mind Mapping Terhadap 
Hasil Belajar Matematika. Journal PGSD Universitas Pendidikan Ganesha Mimbar PGSD, 5(2), 1-10. https://doi.org/http://dx.doi.org/10.23887/jjpgsd.v5i2.10841

Subekti, Y., \& Ariswan, A. (2016). Pembelajaran fisika dengan metode eksperimen untuk meningkatkan hasil belajar kognitif dan keterampilan proses sains. Jurnal Inovasi Pendidikan IPA, 2(2), 252. https://doi.org/10.21831/jipi.v2i2.6278

Supatni, N. M., Dantes, N., Tika, I. N., Studi, P., Pendidikan, E., \& Pascasarjana, P. (2015). Pengaruh Model Pembelajaran Think Pair Share ( Tps ) Terhadap Prestasi Belajar Matematika Dengan Kovariabel Kemampuan Numerik Siswa Kelas Vi Di Sd Gugus Ii Bedulu. E-Journal Program Pascasarjana Universitas Pendidikan Ganesha, 5(1), 1-9.

Susanti, S. (2016). Metode Mind Mapping Untuk Meningkatkan Hasil Belajar Ips Di Sekolah Dasar. Jurnal Pendidikan Guru Sekolah Dasar, 1(1), 25-37. https://doi.org/10.17509/jpgsd.v1i1.9060

Suwitri, N. P. D., Ardana, I. K., \& Negara, I. G. A. O. (2013). Pengaruh Pembelajaran Mind Mapping Berbantuan Media Konkret Terhadap Hasil Belajar IPA Siswa Kelas V SD Gugus III Banjar Anyar Kediri. Mimbar PGSD, 1(1). https://doi.org/http://dx.doi.org/10.23887/jjpgsd.v1i1.1251

Tembang, Y., Sulton, \& Suharjo. (2017). Peningkatan Motivasi Dan Hasil Belajar Melalui Model Pembelajaran Think Pair Share Berbantuan Media Gambar Di Sekolah Dasar. Jurnal Pendidikan, 2(6), 812-817. http://journal.um.ac.id/index.php/jptpp/article/view/9402

Wana, P. R., Pangestu, W. T., \& Agustina, D. A. (2017). Perbandingan Prestasi Belajar Matematika Siswa Dengan Menggunakan Metode Pembelajaran Mind Mapping Dan Direct Instruction Pada Siswa Kelas V Sdn Jiwan 01 Madiun. Trihayu: Jurnal Pendidikan Ke-SD-An, 3(2), 83-88. http://jurnal.ustjogja.ac.id/index.php/trihayu/article/view/837

Wulandari, Abadi, \& Suniasih. (2018). Pengaruh Model Pembelajaran Think Pair Share Berbasis Penilaian Portofolio Terhadap Kompetensi Pengetahuan Ipa Siswa Kelas Iv Sd Negeri Gugus Kapten Kompyang Sujana Denpasar Barat Tahun 2017/2018. MIMBAR PGSD Undiksha, 6(3), 161-168. https://doi.org/http://dx.doi.org/10.23887/jjpgsd.v5i2.10906 